\title{
MAPPING OF DATA COMMUNICATION NETWORKS ON SOCIAL MEDIA
}

\author{
Noviar Jamaal Kholit \\ Universitas Diponegoro Semarang, Indonesia \\ noviar.jamaal@1ecturer.undip.ac.id \\ Muhamad Nastain \\ Universitas Mercu Buana Yogyakarta, Indonesia \\ nastain@mercubuana-yogya.ac.id
}

\begin{abstract}
Information technology is developing very fast, this has an impact on real changes in every element of life. In addition to hitting the information media industry, developments in information technology have brought updates to public spaces with easy access and an increasingly massive pattern of information distribution. Ease of access does not always present a positive side but there is a negative side, namely shifting communication patterns with the spread of false information or disinformation methods that invite public upheaval. This research uses the case study method, which is one way to investigate contemporary phenomena in the context of real life, where the boundaries between the phenomenon and the context are not clearly visible. Through the Social Network Analyzer (SNA) theoretical approach, this research will find three communication network patterns, namely a centralized network, a decentralized network and a distributed network.
\end{abstract}

Keywords: Mapping; Network; Social Media; Social Network Analyzer (SNA)

ACCEPTED :August $8^{\text {th }}, 2020$ REVIEWED: January $26^{\text {th }}, 2021$ PUBLISHED: January $27^{\text {th }}, 2021$

\section{Introduction}

An upload from Sammy Notaslimboy, a comedian who is also a software developer, reminds us of a new chapter when smartphones are starting. The content was uploaded by a comedian whose real name is Sam Darma Putra Ginting on the Twitter platform, on August 7, 2020 
yesterday. "HP-HP baru nan canggih baru pada launching. Tapi belum ada lagi ya orang pingsan ngantri beli hp pas baru launching. Baru Blackberry yang bisa bikin begitu... Wkwkwk", in his @NOTASLIMBOY account. He said about the success of the Blackberry that can make people pass out to buy a cellphone when it is launched, this has not been defeated by the sophisticated cellphones that are being launched today.

Starting from the era of the Blackberry's popularity, smart phones are now familiar to us. Being part of everyday life, smartphones are now not only appearing as accessories. Mobile is a device that is always the first to look for when you wake up and last seen before going to bed then always checked during activities, even taken to the bathroom.

Mobile can be said to be a magic tool in the modern era. Tool, a fairly small size, but can provide satisfaction for its users. Equipped with various applications, users can get what they want. Smartphones are not the fairy godmother in the "Cinderella" story that can give you items that can be used right away, but they give you a sense of satisfaction in another way.

The need for the latest information is one that must be satisfied. With its sophistication, a person can consume information that is not only from the surroundings and even from other parts of the world. Not only are the locations in other areas, the delivery time is almost not intermittent (instantaneously). What happens in other parts of the world, we can get the information right away.

The existence of cellphones is a threat to the mainstream media. The sophistication of a cell phone provides benefits to its users in terms of economics, logistical tools and psychological benefits in the form and lifestyle. The convenience obtained economically is that users do not need to subscribe to newspapers or buy television to access information and entertainment. However, expenses for buying television or subscribing to newspapers are not necessarily eliminated, but are replaced by internet subscription fees.

The diversion of expenditure by cell phone users has an indirect impact on the financial condition of media owners in recent times. Quoted from Kompas.com, August 24, 2019, in 1994 print media circulation in the United States reached more than 60 million copies. This 
number continued to decline, and became 34 million copies in 2018. A number of well-known print media such as Newsweek, Glamor and the UK's well-known newspaper, The Independent, took turns "saying goodbye" during the last five years.

The number of circulation that continues to decline, also causes a number of print media in Indonesia to stop operating. Call it the Jakarta Globe Daily, Koran Tempo and a number of entertainment media such as Tabloid Soccer, Bola Daily, Trax, Rolling Stone and HAI magazine. However, not all print media have stopped completely from their journalistic activities, but only change the medium to reduce the high printing operational costs (Budyastomo, 2018).

Not only does it have economic benefits, mobile phones also provide psychological benefits. Ease of accessing information and communicating is the main choice for device users. The convenience of devices that can be accessed anywhere and anytime makes cellphone users "master the information" faster than before the existence of cellphones. This is evidenced in a survey conducted by GlobalWebIndex, where respondents have an average of 43 minutes of reading print media per day, while online media is consumed for 6 hours 45 minutes per day.

Mobile phone brands also provide lifestyle benefits. At the time of the popularity of Blackberry, the cellphone which was famous for the Blackberry Messenger application appeared to be a marker of social status. Like, a cellphone with a qwerty keyboard, a trackball which later changed the trackpad to become the trend setter of the cellphone at that time. It's not only big brands like Nokia and Samsung that have followed suit to make phones with ergonomic keypads, but less well-known brand phones have a shape similar to Blackberry's.

Blackberry was a phenomenal cellphone, because it became a necessity for fashion. Its sophistication makes people want to have it. As a result, smartphones that were born first with basic operations such as Symbian (Nokia), Java (Sony Ericsson), IOS (apple iphone) had to give up on the sales side.

The advantages possessed by BB cellphones are also a drawback. First, the exclusivity of the instant messenger application BBM has made the providers flaunted where the message sharing application can only be installed on cellphones made by a Canadian manufacturer. While its 
competitor's instant messaging app, Whatsapp, can be installed on smartphones with IOS and android operating systems. Although basically Blackberry can also carry Whatsapp, users must be charged an additional fee because it is not included in the Blackberry Service package. The reason for connectivity between devices then becomes the reason for the decline in Blackberry in the market. Blackberry "can not" connect itself with IOS and Android. While IOS and Android are able to connect to each other with the Whatsapp application which can be used for free with regular internet packages (Subqi, 2020)

Second, instead of being strength, sophistication becomes the mainstay of being the killer. Blackberry has succeeded in becoming a fashion phone, but has failed to be an entertaining cellphone. Call it photo editing applications, games with high resolution are not possible to install on Blackberry phones with screens that are less wide than phones made by Apple and Google. Although finally Blackberry also carried the Android operating system, Blackberry was also unable to increase its sales figures.

Over time, cell phone technology and applications continue to evolve. Image or image editing applications (image processors), games (games) and messaging applications continue to develop themselves. The application categorization is cut by a separate value offered to its users. For example, many applications are basically not image processors, but have the ability to process photos even though they are simple (crop, brightness, contrast). Likewise, the image processing software can also share the processed image, without having to enter the main application first.

The blurring of the restrictions on this application also occurs in the classification of social media. Several years ago, Antony Mayfield (2008) has classified social media based on its type, namely social networks, blogs, wikis, podcasts, forums, content communities and microblogging. In its development, social media's boundaries have become blurred, as each platform carries the specialization of other platforms.

Facebook is one example, where in its development it is able to carry the capabilities of other platforms. The ability to have discussions as a forum and upload for the community with its groups, as well as the 
ability to post long posts as well as blog platforms. Even today, Facebook is also showing its ability as a marketplace to facilitate users who want to buy and sell.

Seeing these developments, it is not surprising that social media is considered a new world. The world that runs simultaneously, runs parallel to the life in the real world. Social media makes it easy for users, gives users 'status' and even becomes a new field of business to change conventional ways of doing business. to the human response in a state of weakness and helplessness, but in so doing he has inherent which is latent (Subqi, 2016).

The main choice when using social media is the ease of getting and spreading content from social media. Forward (forward), copy and paste (copy and paste), share to other platforms (share to other social media platforms) are very helpful tools for social media users to share uploaded content.

The provision of facilities by the platform is of course intended to make users share positive vibes to other users. But not infrequently, content that is disseminated is inappropriate or falls into the category of fake news. As a result, now people find it increasingly difficult to find correct information because of the large number of hoax news circulating.

In a research conducted by Mastel in 2017, the spread of hoaxes did not only occur in mainstream media (television, radio and print media), but also online media (web, chat applications and social media). The percentage level is even greater than the spread of hoaxes through mainstream media.

The highest number of hoax information dissemination through the mainstream media was television, at $8.70 \%$. Meanwhile, the spread of hoaxes through print media and radio was only $1.20 \%$ and $5 \%$, respectively. This number is still relatively small when compared to the percentage of hoax spread through online media, where one of the online media categories has reached a rate of over $90 \%$.

In his research, Mastel classified online media into 3, namely websites, chat applications and social media. From the results of his research, Mastel found $34.90 \%$ of hoax information was spread through websites, $62.80 \%$ was spread through chat applications (Whatsapp, Line, 
Telegram) and the most was through social media (Facebook, Instagram, Twitter and Path) which reached $92.40 \%$.

The Ministry of Communication and Informatics noted in 2016 that there were more than 800 thousand websites indicated as spreading fake news and hate speech. In an effort to reduce the spread of hoaxes, the Ministry of Communication and Information Technology immediately blocks websites that are indicated to have committed these violations.

Apart from the hundreds of thousands of websites that are recorded by Kominfo, there are still thousands and even millions of other sites on the internet network. Many web-based platform sites generate very high and complicated "communication traffic". As a result, the circulation of hoax news became easily accessible to the public and turned into a simple social construction (Bungin, 2017).

The social construction resulting from false information or hoaxes spread in society then becomes increasingly complex when it is connected to the culture of Indonesian society. This is due to a culture of collectivism that is not accompanied by the ability to process data. This is in line as stated (Deddy Mulyana, 2017), that people really like to gather and tell stories, but related to the topics discussed, it is not necessarily true.

Deddy Mulyana also said that Indonesians who lacked a hobby of reading books and now received a lot of exposure to information from "digital platforms" were one of the reasons for hoax news that easily spreads in society. Based on this, people may become "shocked" so that they are unable to filter out what is true or what is not.

Human critical reasoning in warding off or spreading fake news is closely related to the level of literacy (Zamroni \& Sukiratnasari, 2011) states that the level of literacy is related to the level of education and critical power of society. The experience of communication actors is important in analyzing information.

The lack of literacy background for social media users, especially non-journalists, mostly does not care about the accuracy of what is distributed. They are also not disciplined in carrying out a fact check or verification related to information that will be redistributed. This low 
literacy is exploited by "irresponsible content creators" who are only concerned with the reach of the spread of the message.

The distribution of content that then goes viral can evoke emotions. In a study conducted by Jonah Berger and Katherine Milkman (Struhar, 2014), it is shown that viral content can generate very strong positive and negative emotions in its users (high-arousal emotions).

If indeed the content that is disseminated is positive content, of course the positive effects are expected to be spread well. But if the opposite is true, the negative impact that occurs as a result of the distribution of the content becomes uncontrollable. Like its purpose, negative content generally aims to make people unsafe, uncomfortable and confused.

Viral content on social media cannot be separated from features such as shares, likes, hashtags and trending topics. It is undeniable that these features help influence users' reading interest and information consumption. Information can be spread quickly and in a short time even to the right target audience.

Pepitone states, social media has now become one of the technologies whose use continues to increase. Apart from being used as an entertainment tool, social media is also used as a source of information. Social media also gives users the power to spread their ideas to others both interpersonal and also to many people

The ideas that are continuously consumed are then redistributed and developed by other users. The dissemination and development of messages on a social media is proof that social media users are active users where users spread messages, are commented on or given additional new data. The distribution of content on social media content is interesting to study. By looking at the journey of this content, we can see how the data communication network flows on social media and understand how the form of Computer Mediated Communication (CMC) based communication networks is applied to wireless networks on cellular phones.

\section{Research Method}


This research uses a case study method where this method is one of the ways used to investigate contemporary phenomena in the context of real life, where the boundaries between the phenomenon and the context are not clearly visible. The case study research method also has the strength in that it has the ability to combine various types of data collected using several data collection methods. (Rasimin, 2018) The case study method also has the ability to describe something that is unique or peculiar to the phenomenon being studied and tries to offer insights that have broader relevance. (Daymon \& Halloway, 2011).

The application of Robert K. Yin (dalam Tellis, 1997) explained that the case study research method has four functions, namely: (1) Describe the complex causal relationship of phenomena in real life. (2) To describe the real life context in which the phenomenon has occurred. (3) To describe the phenomenon itself. (4) To explore situations where the phenomenon being evaluated does not have clear results

In this study, the sources used were documentation, archival notes and direct observation. This is in line with what was conveyed by Robert $\mathrm{K}$. Yin, where he identified 6 sources that can be used in case study research methods, namely; (1) Documentation, (2) Archive Notes, (3) Interview, (4) Direct Observation, (5) Participant Observation, (6) Physical Artifacts.

The documentation referred to in this study is the result of social media analysis conducted by Ismail Fahmi, a social media analyst who uses Drone Emprit as his tool. The emprit drone itself is his software, to see the map of the distribution of content on social media.

\section{Results and Discussion}

After the 2012 regional elections, the widespread use of the internet for the spread of hoaxes, slander and hate speech was in a dire condition. This can be seen from the number of internet pages that have been closed by Kominfo, because they are considered to be spreading fake news, slander and hate speech. In 2016 alone, the Ministry of Communication and Information detected more than 700 thousand pages that were considered unsettling.

Apart from the website, the hectic spread of content on social media is also troubling. As with websites, social media also plays a role in 
spreading hoaxes, slander and hate speech. In a research conducted by Ismail Fahmi, 92.40\% of hoaxes in Indonesia are spread through social media (Facebook, Twitter, Instagram and Path). In the next sequence, the hoaxes were spread through message sharing applications (Whatsapp, Line, Telegram) as much as $62.80 \%$ and those spread through websites were $34.90 \%$.

Still in the same research, Ismail Fahmi found that the hoaxes spread in Indonesia were mostly social and political issues as well as SARA. The distribution of hoax content related to Social and Political issues was $91.80 \%$, specifically discussing the performance of the government or its policies and related to the regional elections. Meanwhile, the most other issues, as much as $88.60 \%$, were issues related to SARA (ethnicity, religion, race and intergroup).

One of the social issues that has recently been discussed is related to slander towards the actor of the solo comedy (Stand Up Comedy) Bintang Emon. Bintang Emon has been accused of using drugs by several accounts on social media, after uploading a satirical video "accidentally" that was uploaded through me on his social media.

The Bintang Emon case falls into the social category, although what triggers it is entering the political realm, which began with the trial of the perpetrator of pouring hard water on the face of Corruption Eradication Commission (KPK) investigator Novel Baswedan. During the trial of the case, the two perpetrators, Ronny Bugis and Rahmat Kadir Mahulette, admitted that they had accidentally poured hard water on their faces or did not intend to injure Novel Baswedan, which later became one of the two perpetrators to lighten the sentences.

The reason "accidentally" presented by the two perpetrators, received various responses from social media users (netizens). Like @alfathiraja's tweet which wrote:

"Pelakunya beli air keras ga sengaja? Nunggu NB selesai shalat subuh juga gak sengaja? Lalu nyiram air keras ke wajah NB dan bikin cacat 1 matanya juga ga sengaja? dzolim kalian!!".

In the analysis conducted by Ismail Fahmi, between 11 and 15 June 2020, there were 162,162 mentions of conversations on social media about Baswedan Novel. Meanwhile, the accompanying issues, such as 
"accidental" and emon, were 179,320 and 240,990. Of these, the most boisterous talks about Novel Baswedan's news were on Twitter social media.

Talks with the topic accidentally appeared starting on June 11, 2020. These talks peaked on June 13, then tended to fall on June 15, 2020. At its peak (June 13, 2020), there were mentions of "accidentally" in 69,512 posts on Twitter. As for the total mention of the topic "accidentally" as many as 179,320 uploads, came from Indonesian online news media as many as 166 uploads, on Instagram as many as 552 uploads and on Twitter as many as 178,602 uploads.

The topic of "Emon" was also the subject of conversation after Komika Bintang Emon uploaded his opinion about the reasons "accidentally" by the perpetrators. In a humorous way, Komika, with the real name Gusti Muhammad Abdurrahman Bintang Mahaputra, uploaded a video containing his astonishment at the "accidental" action of the two actors pouring hard water on Novel Baswedan.

The video uploaded to his Instagram account has been viewed more than 5 million times. As for the same post on Twitter, it has been retweeted more than 111 thousand times. The viral video made by Bintang Emon turns out to be a long tail. The winner of stand up Comedy Academy 3, which was organized by Indosiar television station in 2017, was under attack on social media. The attack was a slander against Bintang Emon, in the form of a photo with the words "Keeping Emon's Stamina with Drugs" circulating on social media.

Uploads attacking the @bintangemon account owner were uploaded to Twitter at almost the same time, namely on June 14, 2020 at 22:48 WIB. The slanderous-smelling uploads were carried out by the accounts@Tiara61636212,@LiarAngsa and @LintangHanita. The post eventually went viral and grew after the big accounts (owners of many followers) responded to the tweet.

One of the results of social media analysis related to political issues or around government activities (performance and policy) is the controversy over the Mobilizing Organization Program. This controversy erupted when Muhammadiyah, NU and PGRI compactly withdrew from the program initiated by the Minister of Education Nadiem Makarim. 
Muhammadiyah considers the teacher competency improvement program to be unclear and not transparent. Muhammadiyah was also disappointed because it was juxtaposed with organizations that had only emerged in the last few years. The Ma'arif Educational Institution representing NU also expressed the same thing. Moreover, LP Ma'arif did not want to ask for help but in the form of cooperation. Meanwhile, the reason for the Indonesian Teachers Association (PGRI) for the funds allocated for the POP program is not quite right. The PGRI Executive Board assessed that in the midst of the Covid-19 pandemic, the budget should be used to support school infrastructure, students and teachers.

From Ismail Fahmi's analysis using Drone Emprit software, the hubbub of the POP program controversy was widely discussed on July 24,2020 . The analysis, which took a time span between 21 - 29 July 2020 , saw an increase in the number of uploads related to the program on social media. A total of 10,108 uploads came from online news media, social media (Facebook, Twitter, Instagram) and YouTube video sharing.

Twitter is the largest platform for uploading talks about POP programs, namely 8,752 talks (87\%). From a total of 10,108 conversations, after Twitter there were 1,084 (11\%) online media, Facebook with 104 uploads (1\%), Instagram with 167 uploads (2\%) and YouTube only 1 upload (0\%).

This POP-related talk was busy after a number of Twitter accounts uploaded the discussion. Call it the online news media Gelora.co (@geloraco), where the upload was retweeted 1315 times and received 2,773 likes. Uploaded by NU figure, Ahmad Muhaimin Iskandar (@cakimiNOW) was retweeted 1,133 times. This account with 179,439 followers also received 2,548 likes. Apart from @cakimiNOW, there are other figures who also enliven the Ministry of Education and Culture's POP program. Uploaded by members of the Prosperous Justice Party, Hidayat Nur Wahid (@hnurwahid) and a member of the Indonesian Regional Representative Council (DPD), Fahira Idris (@fahiraidris).

The peak of the commotion regarding the upload of the Ministry of Education and Culture's POP controversy occurred on July 24, 2020. There were 3,828 uploads on Twitter on that date after the initial emergence of the issue on July 21, 2020. The discussion related to the Ministry of Education and Culture's POP reached its peak after the 
teacher organization (PGRI) followed Muhammadiyah's footsteps and NU withdrew from the program.

In the case of the POP controversy, there were 5 accounts that became Top Influencers. The @geloraco account with 159,127 followers received 1,315 retweets and 2,773 likes,@cakimiNOW with 1,133 retweets and 2,548 likes, @hnurwahid with 873 retweets and 2,164 likes, @oposisicerdas with 748 likes and 1,472 likes and @suaraharian_com with 640 likes and 1,620 like.

A case that is categorized as a case of SARA (ethnicity, religion, race and intergroup) which is widely discussed on social media is the UnIslamic Cake Klepon. The discussion about this un-Islamic klepon cake began to get busy on July 21, 2020. The conversation on Facebook was busy first, then social media Twitter and Instagram followed.

Analysis carried out on July 21, 2020, Drone Emprit caught 49,021 mentions related to un-Islamic klepon. This number is classified as follows, from the news media of 482 mentions, Facebook 701 mentions, Instagram 374 mentions and Twitter 47,464 mentions.

This initial post that triggered the crowd was uploaded on the Facebook platform by the Erwin Rabbani II account (fb.com/ErwinRabbani2). Even though it has been deleted, the Internet Archive shows that the sara-related content was uploaded on July 20, 2020 at 20.31 WIB. From the data displayed by Drone Emprit, the conversation about klepon cake on Facebook peaked on July 21, 2020 at 8 am with 203 mentions.

Meanwhile, at the same time, conversations on Twitter only reached 51 mentions and the peak occurred at 18.00 WIB with 10,066 mentions. On the Twitter platform, klepon content was first uploaded by abah_zs (@zsumarsono) at 5.40 WIB. While the initial trend occurred at 6 o'clock and started to crawl up at 8 o'clock in the morning.

On this issue, the 5 Top Influencers in the initial phase were the Indigenous Kawe account (@jr_kw19) with 51 retweets and 166 likes, Junto (@jumianto_RK) which was retweeted 39 times and received 90 likes, Nashir (@Rahman_Nashir)who retweeted 23 times with as many as 50 likes, diblos (@AL_diablos) with 13 retweets and 4 likes and Indri Yahya (@MrsRachelln)with 13 retweets and 36 likes. 
The Klepon Un-Islamic issue then grew and was busy being discussed after big accounts (having many followers) joined in to enliven it. Overall, the @Irenecutemom account received the most retweets, namely 6,546 and 19,039 likes. Followed by other accounts such as @TretanMuslim, @jawafess, @FiersaBesari and @Ridwanhr which received retweets between 2,000 and 6,500 times.

From the 3 data summarized, it can be seen the patterns of message dissemination on social media networks. In Social Network Analysis (SNA), several points are seen to be the center of message dissemination. The process of spreading messages can occur because of the network that connects various communication devices in different places.

The ability to communicate with each other between these tools cannot be separated from the development of Computer Mediated Communication (CMC). Although initially, the communication process only sent text messages from one computer to another, which were typed using the keyboard and visible on the monitor screen (Herring dalam Schiffrin, 2001).

The SNA map obtained using the Emprit drone was previously mapped by Paul Baran (1964). In his writing, Baran mapped 3 communication network patterns, namely (a) centralized networks, (b) decentralized networks and (c) distributed networks.

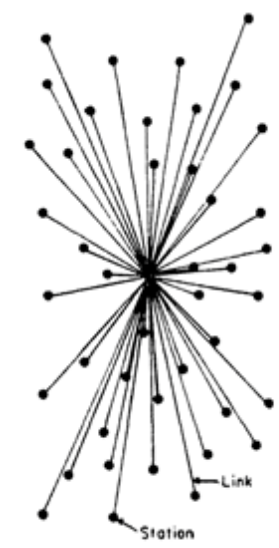

(a)

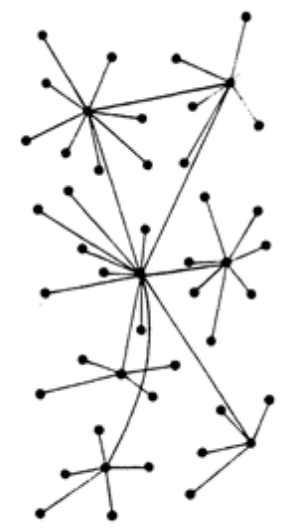

(b)

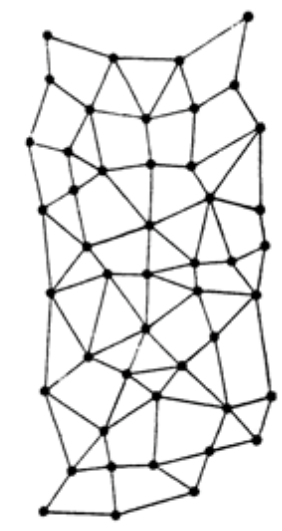

(c)

Picture 1. Paul Baran Network Models (1964)

Centralized Network is a network that is centered on a point. This point can be the starting point where the message begins to be uploaded 
to social media. Of course, this message has not been redistributed and there has been no development or change in the uploaded content (message).

The second form, the decentralized network, can be called an advanced stage of the centralized network communication process. Where the message is distributed to message centers first before being spread to a wider audience. This decentralized network process can happen over and over again until it becomes saturated. It is in this process that we can see how the journey of content on social media has gone viral.

The third form is a distributed network. Unlike the first and second processes, this process connects all network users where ordinary users will find it difficult to see where the message center is. With this distributed network, anyone can be the center of the message (sender of the first message) and can be distributed by other users.

Furthermore, the current form of networking on social media does not use one form, but all three can run simultaneously on social media. To get a more specific picture, we can see how connected each Twitter user is from the following image.

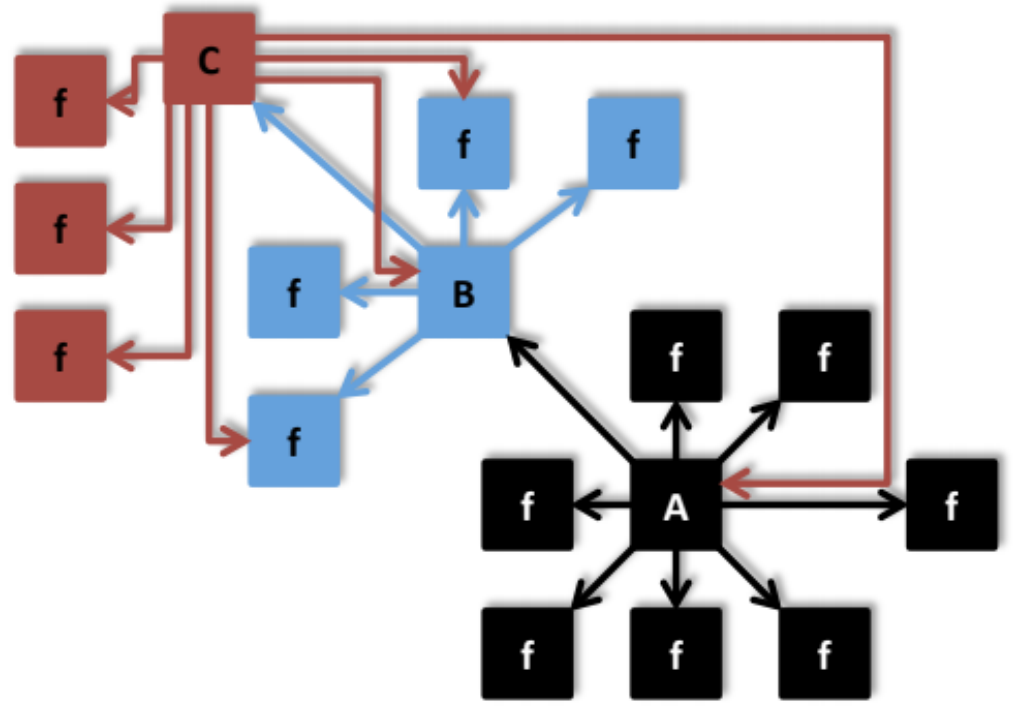

Picture 2: Flow of Message Spread on Social Media

\section{Note:}

$\mathrm{A}, \mathrm{B}, \mathrm{C}=$ Message creator $/$ uploader 

---> $\quad=$ The process of sending messages to followers / connecting twitter users
$\mathrm{F} \quad=$ Follower

There are 3 colors in the form of a network or connection to Twitter users. Each of these colors indicates a communication cluster in a connection between Twitter users. In each cluster, users who are followers can see or receive messages from whom they follow.

Each color represents the first form of the Paul baran network, the centralized network. A, B and C become the center or creator of messages that can be accepted by their respective followers $(F)$. In the black cluster, $\mathrm{B}$ is a follower of $\mathrm{A}$ and $\mathrm{C}$ is a follower of $\mathrm{B}$ in the blue cluster. However, in the red cluster, $\mathrm{A}$ and $\mathrm{B}$ turned out to be followers of C.

If the clusters are combined, it will look like a decentralized network. In this case A, B and C become the center or maker of messages where the message can be seen by the followers of each cluster. By looking at the arrows in the image, who is the recipient of the message can be seen.

The complexity of this network form will begin to appear if this connected cluster is very large. Where A, B and C are no longer the center or message maker, but each follower seen in the picture forms another cluster and becomes the center or message maker itself. Finally, the complexity of the clusters forms a separate network form or a distributed network form.

Clusters on the twitter social media network were determined by follow activity. Users who follow an account will become part of a cluster. In other words, if there are 2 Twitter users who follow each other, it means that it will form 2 new clusters even though the two Twitter users are in a different cluster.

Due to the characteristics of open social media, communication between users is also possible for others to see. Although preparing a special channel for personal communication, in general, the communication or message sending process is carried out openly with random recipients but still in the cluster environment. 
Besides being open, Mayfield (2010) also mentions that the characteristics of social media are connectedness. Thus, social media does not only connect people, but also connects between clusters. Because, each Twitter user can be part of more than 1 cluster, apart from the cluster he created himself.

\section{Conclusion}

The pattern of communication networks and dissemination of messages on social media, especially Twitter, uses several points as centers of information dissemination. The communication network pattern takes place in three patterns, namely the Centralized Network, the decentralized network and the distributed network. The first pattern, Centralized Network, is a network that is centered on a point. This pattern takes place when the message is still original in production and has not received additional information that can make a change in perception. The emon star case can be an example of how this pattern takes place where the production of messages is only centered on the upload without being contaminated with other messages.

The second form, decentralized network, where the message is distributed to message centers first before being spread to wider recipients. This process can take place simultaneously until it causes saturation of issues or messages to the public. The case of the withdrawal of Muhammadiyah and NU from the Movement Organization Program (POP) which was initiated by the Ministry of Education and Culture can be a case study of a decentralized network. Initial information was produced, not just one or two accounts, then lots of replies or comments were made, resulting in large numbers of repeated conversations. POP related uploads that reached 10,108 in just 9 days were uploaded by many social media accounts.

The third form is a distributed network. Unlike the first and second processes, this process connects all network users where ordinary users will find it difficult to see where the message center is. With this distributed network, anyone can be the center of the message (sender of the first message) and can be distributed by other users. The production of messages in this pattern does not have a single epicenter due to issues or messages being raised (uploaded) simultaneously by several accounts on 
social media. The case of the un-Islamic klepon cake which has attracted a lot of public attention can be used as a case study of a distributed network pattern. The issue of SARA in the un-Islamic Cake Klepon uploads has received a lot of uploads by several accounts with large followers and with various interests of Issu. On the one hand, there are those who construct issues that discredit one of the movement's "ideologies" which are often called radical and intolerant, while on the other hand upload rebuttals to the issue. This is what makes the message uploads not have a single epicenter because messages are distributed across multiple accounts on social media.

\section{Bibliography}

Bungin, B. 2017. Politik Hyperreality dan Communication Jammed dalam buku Turn Back Hoax Tantangan Literasi Media Digital. Surabaya: Buku Litera dan Aspikom Korwil Jawa Timur

Budyastomo, A. W. (2018). Bentuk Bahasa Komunikasi dalam Seni

Grafiti Sebagai Media Penyampaian Pesan (Studi Kasus: Padepokan Grafiti Salatiga). Batoboh, 3(2), 146-156.

Daymon, Christine \& Halloway, Immy. 2011. Riset Kualitatif dalam Public Relations \& Marketing Communications. Yogyakarta: IKAPI

Gumilar, Gumgum, Justito Adiprasetio dan Nunik Maharani. 2017. Literasi Media: Cerdas Menggunakan Media Sosial Dalam Menanggulangi Berita Palsu (Hoax) Oleh Siswa SMA. Jurnal Pengabdian Kepada Masyarakat. Vol. 1 No. 1, Februari 2017: 35 $-40$

Juditha, Christiany. (2018)." Interaksi Komunikasi Hoax di Media Sosial serta Antisipasinya". Jurnal Perkomnas. Vol. 3 No. 1: 31 - 44.

Kholit, Noviar Jamaal. 2014. Komunikasi Pemasaran Melalui Twitter (Studi Kasus Pesan dan Jangkauan Pada Twitter Program Acara NEZ ACADEMY NET). Universitas Mercu Buana

Majid, Abdul. 2019. Fenomena Penyebaran Hoax dan Literasi Media Sosial Lembaga Mahasiswa Universitas Muslim Indonesia. Jurnal Komodifikasi. Vol. 8: 228-229

Mayfield, Antony. 2008. What is Social Media: An e-book From Crossing. San Francisco, USA. 
Mulyana, Deddy. 2014. Ilmu Komunikasi: Suatu Pengantar. Cetakan ke 18. Bandung: Remaja Rosdakarya.

Nicolle, S. (2004). Deborah Schiffrin, Deborah Tannen \& Heidi E. Hamilton (eds.), The handbook of discourse analysis (Blackwell Handbooks in Linguistics). Oxford: Blackwell Publishers, 2001. Pp. $\quad \mathrm{xx}$ 851. Journal of Linguistics, 40(1), 192-198. doi:10.1017/S0022226703292367

Rasimin, R. (2018). Metodologi Penelitian: Pendekatan Praktis Kualitatif. Yogyakarta: Trussmedia

Subqi, I. 2016. Pola Komunikasi Keagamaan dalam Membentuk Kepribadian Anak. INJECT (Interdisciplinary Journal of Communication), 1(2), 165-180.

Subqi, I. (2020). Psikologi Sosial. Yogyakarta: Trussmedia

Zamroni, M., \& Sukiratnasari. 2011. KPID DIY Membumikan Literasi Media Bagi Masyarakat di Daerah Istimewa Yogyakarta. In D. Herlina, Gerakan Literasi Media Indonesia. Yogyakarta: Rumah Sinema

Winkelmann, S (ed). 2012. The Social media (R)evolution? Asian Perspectives on New Media. Singapore: Konrad-AdenauerStiftun.

Zamroni, M., \& Sukiratnasari. (2011). KPID DIY Membumikan Literasi Media Bagi Masyarakat di Daerah Istimewa Yogyakarta. In D. Herlina, Gerakan Literasi Media Indonesia. Yogyakarta: Rumah Sinema

\section{Internet}

Cnnindonesia.com. (2016, Desember 29). Ada 800 Ribu Situs Penyebar Hoax di Indonesia. Diakses pada 7 Agustus 2020, dari https://www.cnnindonesia.com/teknologi/20161229170130-185182956/ada-800-ribu-situs-penyebar-hoax-di-indonesia

Detik.com. (2020, Februari 5). Ponsel BlackBerry Terancam 'Disuntik' Mati. Diakses pada 29 Juli 2020, dari https://inet.detik.com/consumer/d-4886355/ponsel-blackberryterancam-disuntik-mati

Detik.com. (2020, Juni 16). Viral Bintang Emon Komentari Kasus Novel Baswedan. Diakses pada 14 Agustus 2020 dari 
https://hot.detik.com/celeb/d-5054818/viral-bintang-emonkomentari-kasus-novel-baswedan

Fahmi, Ismail. 2017. Perilaku Masyarakat Indonesia terhadap Hoax Media dan Budaya Baca. Diakses pada 15 Agustus 2020 dari https:// www.slideshare.net/IsmailFahmi3/perilakumasyarakatindonesia-terhadap-hoax-mediadan-budaya-baca

Fahmi, Ismail. 2020. Bintang Emon \#Gaksengaja. Diakses pada 14 Agustus 2020, dari https://www.slideshare.net/IsmailFahmi3/bintang-emon-gaksengaja

Fahmi, Ismail. 2020. Kontroversi POP Kemdikbud. Diakses pada 14 Agustus 2020, dari https://www.slideshare.net/IsmailFahmi3/kontroversi-popkemdikbud

Fahmi, Ismail. 2020. Kue Klepon Tidak Islami. Diakses pada 14 Agustus 2020, dari https://www.slideshare.net/IsmailFahmi3/kue-klepontidak-islami

Kompas.com. (2017, Februari 8). Kenapa "Hoax" Mudah Tersebar di Indonesia? Diakses pada 7 Agustus 2020, dari https://megapolitan.kompas.com/read/2017/02/08/21160841/k enapa.hoax.mudah.tersebar.di.indonesia

Kompas.com. (2019, Agustus 24). Akankah TV Bernasib Sama dengan Koran dan Majalah. Diakses pada 29 Juli 2020, dari https://www.kompas.com/tren/read/2019/08/24/071300965/a kankah-tv-bernasib-sama-dengan-koran-dan-majalah

Mastel.id. (2017, Februari 13). Hasil Survey Wabah HOAX Nasional 2017. Diakses pada 7 Agustus 2020, dari https://mastel.id/hasilsurvey-wabah-hoax-nasional-2017/

Solopos.com. (2020, Juli 26). Ini Alasan Muhammadiyah, NU, Dan PGRI Mundur Dari POP Nadiem Makarim. Diakses pada 16 Agustus 2020, dari https://www.solopos.com/ini-alasanmuhammadiyah-nu-dan-pgri-mundur-dari-pop-nadiem-makarim1072673

Viva.co.id. (2020, Juni 12). Terdakwa 'Gak Sengaja' Siram Novel Baswedan, Warganet: Negara Lawak. Diakses pada 14 Agustus 2020, dari https://www.viva.co.id/berita/politik/1221635- 
terdakwa-ga-sengaja-siram-novel-baswedan-warganet-negaralawak. 